\title{
The Role of Ice Nucleation-active Bacteria on Frost Damage of Tea Plants
}

\author{
Masao GoTo*, Masahiko KomaBA*, Tomohiro HoRIKAWA** \\ and Noriyuki NAKAMURA***
}

\begin{abstract}
Buds and folded terminal leaves on young shoots of tea plant (Camellia sinensis (L.) Kuntze) carried gemmisphere bacteria at the median population of $2.8 \times 10^{6} \mathrm{cfu} / \mathrm{bud}$ or $4.8 \times 10^{7} \mathrm{cfu} / \mathrm{g}$. The bacteria were detected in a log normal distribution and characterized with high population of ice nucleation-activity negative, irregularly-shaped, Gram-positive and orange colored colony formers. The ice nucleation-active (INA) bacteria, Xanthomonas campestris and Envinia ananas, were the components of these gemmisphere bacteria. $X$. campestris was predominant all year round, the median population being $5.5 \times 10^{4}$ $\mathrm{cfu} / \mathrm{bud}$ in contrast to $3.1 \times 10^{2} \mathrm{cfu} / \mathrm{bud}$ in $E$. ananas, although the populations varied depending on the localities, fields, growth stages of tea plants and/or neighboring plant species. No relationship was confirmed between the distribution frequency and/or population of these INA bacteria and frost damage induced under either natural conditions or artificial ones as well as freeze injuries inflicted on aseptically cultured shoots. Young leaves growing in field suffered freeze injuries at -2 to $-3^{\circ} \mathrm{C}$ irrespective of the degree of leaf expansion, suggesting the involvement of plant intrinsic ice nuclei rather than INA bacteria in the frost damage of tea plant.
\end{abstract}

(Received April 12, 1993)

Key words: Tea, ice nucleation-active bacteria, frost damage, gemmisphere bacteria.

\section{INTRODUCTION}

Plants hold as epiphytes various ice nucleation-active (INA) bacteria which initiate ice crystal formation from supercooled water at -2 to $-3^{\circ} \mathrm{C}^{15,22)}$. These bacteria have been intensively studied in relation to frost damage on the basis of the following observations: 1) substantial freeze injuries occur when plants were sprayed with INA bacteria at high concentrations and subjected to $-5^{\circ} \mathrm{C}$ for a few to several hours ${ }^{2,4,6,13.16-19)}$, and 2) the plants sprayed with INA bacteria may be protected from freeze injuries to some extent by treatment with bactericides ${ }^{1,10,14,21)}$. The positive relationship between INA bacteria and freeze injuries in these investigations have often been drawn from the experiments conducted in growth chambers with artificially infested plants. Under natural conditions, however, considerable controversies have been arisen about the role of epiphytic INA bacteria as the initiator of frost damage because no relationship could be observed between the presence of INA bacteria and occurrence of frost damage ${ }^{2,3,11,12)}$.

In Japan the first flush of tea plant often suffer severe frost damage in late April, the economic losses being not uncommon to sum up 1 to 2 billion yen in Shizuoka Prefecture alone. To avoid such frost damage, 12 to 15 air-stirring electric fans per hectare are usually installed in tea field $8 \mathrm{~m}$ above ground with the approximate cost of 3.5 million yen. The possible involvement of INA bacteria in such frost

\footnotetext{
- Faculty of Agriculture, Shizuoka University, 836 Ohya, 422 Shizuoka. Japan 静岡大学農学部

**Agricultural Technology Division, Shizuoka Prefecture, 9-6 Ohte-machi, 420 Shizuoka, Japan 静岡県農業技 術課

*** Shizuoka Tea Experiment Station, Kurasawa, Kikugawa-cho, 439 Shizuoka, Japan

静岡県茶業試験場
} 
damage had, therefore, attracted considerable interests of farmers as well as scientists from the viewpoints of development and/or application of chemical or biological strategies to control frost damage which had been reported to be effective in other plants ${ }^{1,14,21)}$.

The present study was conducted to prove the role of INA bacteria on frost damage of tea buds/ leaves from the following points of view : 1) distribution frequency and population dynamics of INA bacteria in tea field, and 2) relationships between INA bacteria and frost damage or freeze injuries generated under natural and artificial conditions.

\section{MATERIALS AND METHODS}

Plant materials. Tea buds/leaves used for isolation of INA bacteria were collected from the specified tea fields surrounding the campus of Shizuoka University. Overwintered, aged shoots with terminal and axillary buds or young shoots with folded slender terminal leaf and two to three unfolding leaves were sampled with sterilized forceps into polyethylene bags and brought to laboratory. The explants for tissue culture were obtained from Shizuoka Tea Experiment Station and propagated on the modified Murashige and Skoog agar medium described below.

Isolation of gemmisphere bacteria. An unsprouted bud on aged shoots or a folded terminal leaf on new sprouts was macerated in $1 \mathrm{ml}$ of sterilized distilled water and serially diluted to $1: 10$ with sterilized water. The population of bacteria was counted by plating $100 \mu 1$ of each dilution on nutrient agar plates (yeast extract $5 \mathrm{~g}$, peptone $10 \mathrm{~g}$, agar $15 \mathrm{~g}, \mathrm{H}_{2} \mathrm{O} 1,000 \mathrm{ml}, \mathrm{pH} 6.8$ ) and incubating these plates at $28^{\circ} \mathrm{C}$ for 5 days.

Isolation of INA bacteria. The buds on overwintered shoots or folded terminal leaves on newly developed shoots were excised with forceps and thoroughly macerated in $1 \mathrm{ml}$ of sterilized distilled water. The suspensions were subjected to the 10 -fold serial dilutions and $100 \mu l$ of each dilution was plated on two selective media NSVA and SGNA which were developed for INA-E. ananas and for INA-X. campestris, respectively ${ }^{8)}$. The agar plates were incubated at $28^{\circ} \mathrm{C}$ for 2 days for $E$. ananas and 4 days for $X$. campestris.

Determination of ice nucleation activity. Bacteria were suspended in sterilized distilled water at approximate concentrations of $10^{8} \mathrm{cfu} / \mathrm{ml}$ and 10 droplets of $10 \mu 1$ of these suspensions were placed on an aluminum sheet which was floated on methanol cooled down beforehand to $-5 \pm 0.2^{\circ} \mathrm{C}$ with COOL ACE (CA-101L) (TKK Ltd., Tokyo). Bacterial strains were identified as INA bacteria when all droplets freezed within $30 \mathrm{sec}$.

Induction of artificial frost. The frost box was designed for inducing artificial frost due to emission of infra-red radiation from leaf surface. It was $3.2 \mathrm{~m}^{2}$ in area and $1 \mathrm{~m}$ in height with no bottom. The polyurethane was installed in the wall for insulating heat rays. The box was placed in field so as to keep a $1.8 \mathrm{~m}$ long row of tea plants inside. Dried rice straws were spread on the ground about $15 \mathrm{~cm}$ in thickness to shut off emission of infra-red radiation from ground. A polyethylene film was then spread on top of the box. The night temperature of air and leaf surface both inside and outside the box were monitored with a computer every five minutes.

Tissue culture of tea plant. Murashige and Skoog (MS) agar medium was used with some modifications. The amount of macro ingredients such as $\mathrm{NH}_{4} \mathrm{NO}_{3}, \mathrm{KNO}_{3}, \mathrm{CaCl}_{2} \cdot 2 \mathrm{H}_{2} \mathrm{O}, \mathrm{MgSO}_{4} \cdot 7 \mathrm{H}_{2} \mathrm{O}$ and $\mathrm{KH}_{2} \mathrm{PO}_{4}$ was reduced to $1 / 2$ of the original recipe, and indoleacetic acid, benzyladenine and gibberellin were added at the final concentrations of $0.01,1.0$ and $5.0 \mathrm{ppm}$, respectively.

Stress treatment. With new shoots sampled in field, the folded terminal leaf was removed and the second and third leaves unfolding in a half way were dipped in a $0.05 \%$ sodium hypochlorite solution for $10 \mathrm{~min}$, washed with sterilized distilled water three times, and dried in air. Preliminary tests proved that this treatment destroyed all epiphytic microorganisms on unfolding leaves. With explants grown on MS medium, vigorously growing shoots several $\mathrm{cm}$ in length were used.

These plant materials were dipped in the suspensions of INA bacteria at the concentrations of about $10^{8} \mathrm{cfu} / \mathrm{ml}$ for $5 \mathrm{~min}$ and dried in air. The shoots loaded with INA bacteria were fixed on a polyurethane block, $8 \mathrm{~cm}$ in diameter and $1 \mathrm{~cm}$ in thickness, by inserting the basal end of stem. Five to ten shoots were 
used for each treatment depending on the size of shoots. The shoots immersed in sterilized distilled water instead of bacterial suspension were used as the control. The block was placed in glass beaker, and the shoots were arranged on the block so as to locate at the same distance from the wall of glassware. The glassware was placed in a methanol bath and gently cooled down. Temperatures were recorded every minutes by two sensors, one of which was located between leaves at the same height and another fixed on the surface of a leaf.

\section{RESULTS}

\section{Bacterial population in tea gemmisphere}

The total bacteria in gemmisphere showed log normal populations with the median population of $2.8 \times 10^{6} \mathrm{cfu} / \mathrm{bud}$ or $4.8 \times 10^{7} \mathrm{cfu} / \mathrm{g}$. The populations on the second and third unfolded leaves were $5.7 \times$ $10^{4} \mathrm{cfu} /$ leaf in average, indicating rapid decline after unfolding. The bacterial flora of tea gemmisphere was characteristic in that the ice nucleation-activity negative, irregularly-shaped. Gram-positive and orange-colony formers were predominant (data not shown).

Seasonal population change of INA bacteria in tea gemmisphere

The distribution frequency and populations of INA bacteria were analyzed in seven different tea

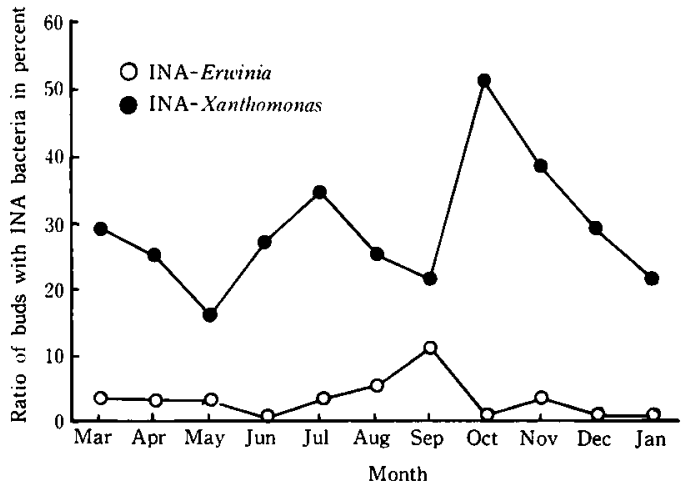

Fig. 1. Representative population change of INA bacteria in gemmisphere of tea plants.

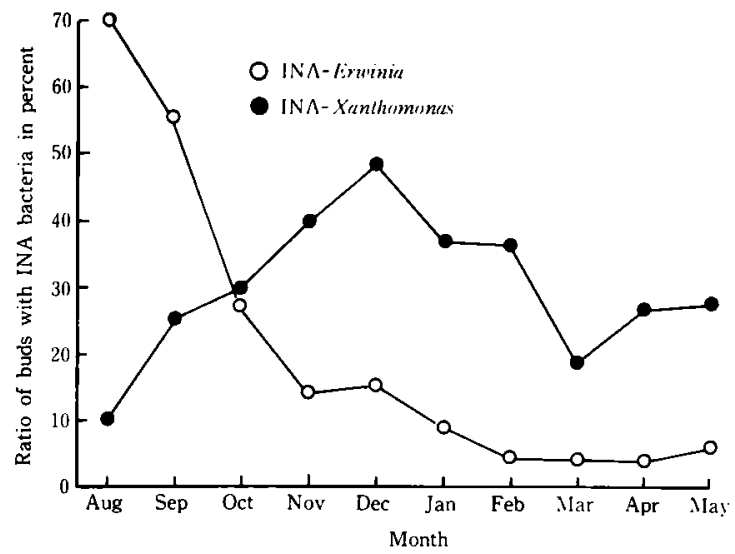

Fig. 2. Seasonal population change of INA bacteria on new flush of shoots from stubs that were cut down for regeneration of tea plants. 
fields from March, 1989 through January, 1990. Non-pathogenic $X$. campestris and E. ananas ${ }^{7)}$ were the major components of INA bacteria on tea plants. Typical patterns of the seasonal population change in both INA bacteria were shown in Fig. 1. Distribution frequency of INA bacteria was considerably different depending on locations, fields and/or growth stages, it ranged from 0 to $20 \%$ for E. ananas and 20 to $70 \%$ for $X$. campestris, respectively. $X$. campestris was the major component of INA bacteria and detected from $28.7 \%$ buds in average. In contrast, the distribution of Envinia ananas was generally minor and detected from only $3.5 \%$ buds in average.

$X$. campestris was always predominant all year round at the median population of $5.5 \times 10^{4} \mathrm{cfu} / \mathrm{bud}$, whereas $E$. ananas at $3.1 \times 10^{2} \mathrm{cfu} /$ bud. The populations of INA bacteria were significantly different

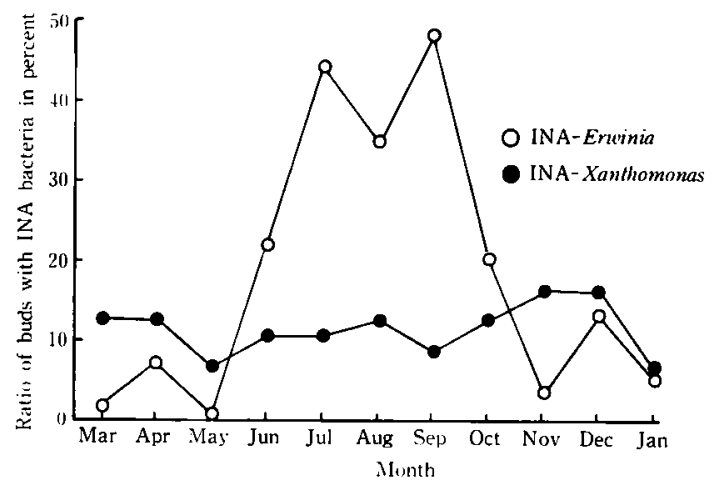

Fig. 3. Seasonal population change of INA bacteria in gemmisphere of tea plants in bush of abandoned field.

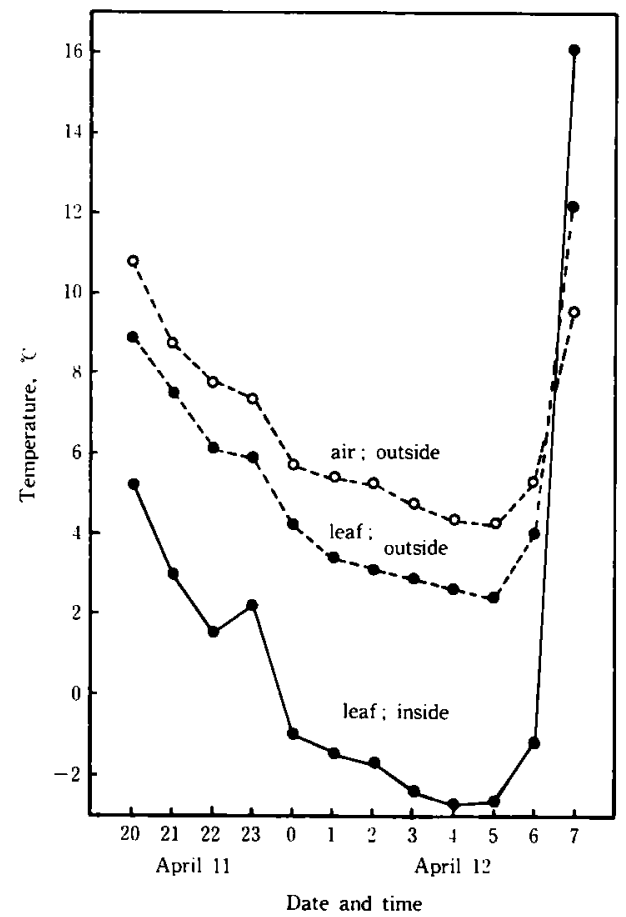

Fig. 4. Temperature of air and tea leaves of the inside and outside frost box (1989) 
depending on the physiological conditions and growth stages of tea plant. For example, E. ananas was dominant on first flush from stubs which were cut down for regeneration of tea plant, but the population quickly shifted toward that of adult plants as shoots became matured (Fig. 2). E. ananas was also dominant on abandoned tea plants grown in bush of miscellaneous plants (Fig. 3).

Relationship between the population of INA bacteria and occurrence of frost damage in the frost box

The experiments were conducted three times at the Shizuoka Tea Experiment Station in early morning of April 12 and 29, 1989 and April 25, 1990. An artificial frost box was set in the tea field when clear sky with no wind was forecasted by the local meteorological bureau. Figure 4 shows air temperature and temperature of leaf surface during the night. The temperature of leaf surface in the box was 5 to 6 degrees lower than that outside the box. The lowest temperature of the former reached to $-3^{\circ} \mathrm{C}$ for about $1 \mathrm{hr}$ before sunrise when frost injury was generated. The results were shown in Table 1 to 3 . The frost damage was classified into three categories of severely injured, slightly injured and not injured, and the populations of INA bacteria in folded terminal leaves of each category were counted. No significant differences at $5 \%$ level were detected in the distribution frequencies of INA bacteria between young shoots with and without frost damage. In other words, the frost damage occurred irrespective of the presence of INA bacteria, or INA bacteria were detected from tea leaves regardless of the frost damage and its intensity.

Table 1. Relationship between ice nucleation-active bacteria and frost damage artificially induced with the frost box on April 12, 1989

\begin{tabular}{|c|c|c|c|c|c|c|c|c|c|c|}
\hline \multirow{3}{*}{ Site } & \multirow{3}{*}{$\begin{array}{l}\text { Intensity } \\
\text { of } \\
\text { damage }^{a)}\end{array}$} & \multirow{3}{*}{$\begin{array}{c}\text { Number } \\
\text { of buds } \\
\text { used }\end{array}$} & \multicolumn{8}{|c|}{ No. of buds carried INA bacteria } \\
\hline & & & \multicolumn{4}{|c|}{ E. ananas } & \multicolumn{4}{|c|}{$X$. campestris } \\
\hline & & & $3+b$ & $2+$ & + & - & $3+$ & $2+$ & + & - \\
\hline \multirow{3}{*}{$\begin{array}{l}\text { Inside } \\
\text { frost box }\end{array}$} & Severe & 96 & 0 & $\begin{array}{c}2 \\
(2.1)^{\mathrm{e}}\end{array}$ & $\begin{array}{c}1 \\
(1.0)\end{array}$ & $\begin{array}{c}93 \\
(96.9)\end{array}$ & $\begin{array}{c}9 \\
(9.4)\end{array}$ & $\begin{array}{c}2 \\
(2.1)\end{array}$ & $\begin{array}{c}1 \\
(1.0)\end{array}$ & $\begin{array}{c}84 \\
(87.5)\end{array}$ \\
\hline & Light & 96 & 0 & $\begin{array}{c}3 \\
(3.1)\end{array}$ & $\begin{array}{c}4 \\
(4.2)\end{array}$ & $\begin{array}{c}89 \\
(92.7)\end{array}$ & $\begin{array}{c}9 \\
(9.4)\end{array}$ & $\begin{array}{c}5 \\
(5.2)\end{array}$ & $\begin{array}{c}7 \\
(7.2)\end{array}$ & $\begin{array}{c}75 \\
(78.1)\end{array}$ \\
\hline & None & 60 & 0 & 0 & 0 & $\begin{array}{c}60 \\
(100) \\
\end{array}$ & $\begin{array}{c}2 \\
(3.3) \\
\end{array}$ & 0 & 0 & $\begin{array}{c}58 \\
(96.7) \\
\end{array}$ \\
\hline $\begin{array}{l}\text { Outside } \\
\text { frost box }\end{array}$ & None & 96 & 0 & 0 & $\begin{array}{c}1 \\
(1.0)\end{array}$ & $\begin{array}{c}95 \\
(99.0)\end{array}$ & $\begin{array}{c}20 \\
(20.8)\end{array}$ & $\begin{array}{c}1 \\
(1.0)\end{array}$ & $\begin{array}{c}12 \\
(12.5)\end{array}$ & $\begin{array}{c}63 \\
(65.6)\end{array}$ \\
\hline
\end{tabular}

a) Severe : new shoots with a folded terminal leaf and two unfolding leaves totally suffered from frost damage. Light: about half of leaf lamina suffered from frost damage.

b) Bacterial density : $3+$ above $10^{6-7} \mathrm{cfu} / \mathrm{ml} ; 2+10^{4-5} \mathrm{cfu} / \mathrm{ml}$; + less than $10^{2-3} \mathrm{cfu} / \mathrm{ml}$; - none.

c) Figures in brackets are ratios in percent.

Table 2. Relationship between ice nucleation-active bacteria and frost damage artificially induced with the frost box on April 29, $1989^{\text {a) }}$

\begin{tabular}{|c|c|c|c|c|c|c|c|c|c|c|}
\hline \multirow{3}{*}{ Site } & \multirow{3}{*}{$\begin{array}{c}\text { Intensity } \\
\text { of } \\
\text { damage }\end{array}$} & \multirow{3}{*}{$\begin{array}{c}\text { Number } \\
\text { of buds } \\
\text { used }\end{array}$} & \multicolumn{8}{|c|}{ No. of buds carried INA bacteria } \\
\hline & & & \multicolumn{4}{|c|}{ E. ananas } & \multicolumn{4}{|c|}{$X$. campestris } \\
\hline & & & $3+$ & $2+$ & + & - & $3+$ & $2+$ & + & - \\
\hline \multirow{6}{*}{$\begin{array}{l}\text { Inside } \\
\text { frost box }\end{array}$} & Severe & 54 & 0 & 0 & 8 & 46 & 4 & 1 & 4 & 45 \\
\hline & & & & & (14.8) & $(85.2)$ & (7.4) & (1.9) & $(7.4)$ & $(83.3)$ \\
\hline & Light & 54 & 0 & 1 & 9 & 44 & 3 & 0 & 2 & 49 \\
\hline & & & & $(1.9)$ & $(16.7)$ & $(81.5)$ & $(5.6)$ & & $(3.7)$ & $(90.7)$ \\
\hline & None & 54 & 0 & 1 & 3 & 50 & 0 & 0 & 1 & 53 \\
\hline & & & & (1.9) & (5.6) & (92.6) & & & (1.9) & $(98.1)$ \\
\hline \multirow{2}{*}{$\begin{array}{l}\text { Outside } \\
\text { frost box }\end{array}$} & None & 54 & 0 & 0 & 0 & 54 & 4 & 3 & 1 & 46 \\
\hline & & & & & & $(100)$ & (7.4) & (5.6) & (1.9) & $(85.2)$ \\
\hline
\end{tabular}

a) Explanatory remarks : see Table 1 . 
Table 3. Relationship between ice nucleation-active bacteria and frost damage artificially induced with the frost box on April 25, 1990"

\begin{tabular}{|c|c|c|c|c|c|c|c|c|c|c|}
\hline \multirow{3}{*}{ Site } & \multirow{3}{*}{$\begin{array}{c}\text { Intensity } \\
\text { of } \\
\text { damage }\end{array}$} & \multirow{3}{*}{$\begin{array}{c}\text { Number } \\
\text { of buds } \\
\text { tested }\end{array}$} & \multicolumn{8}{|c|}{ No. of buds carried INA bacteria } \\
\hline & & & \multicolumn{4}{|c|}{ E. ananas } & \multicolumn{4}{|c|}{ X. campestris } \\
\hline & & & $3+$ & $2+$ & + & - & $3+$ & $2+$ & + & - \\
\hline \multirow{4}{*}{$\begin{array}{l}\text { Inside } \\
\text { frost box }\end{array}$} & Severe & 54 & 0 & 0 & 2 & 52 & 1 & 2 & 0 & 51 \\
\hline & & & & & $(3.7)$ & $(96.3)$ & (1.9) & (3.7) & & (94.4) \\
\hline & None & 54 & 0 & 0 & 1 & 53 & 4 & 2 & 1 & 47 \\
\hline & & & & & (1.9) & (98.1) & $(7.4)$ & (3.7) & (1.9) & $(87.0)$ \\
\hline \multirow{2}{*}{$\begin{array}{l}\text { Outside } \\
\text { frost box }\end{array}$} & None & 72 & 0 & 0 & 0 & 72 & 2 & 1 & 0 & 69 \\
\hline & & & & & & $(100)$ & $(2.8)$ & (1.4) & & (95.8) \\
\hline
\end{tabular}

a) Explanatory remarks: see Table 1 .

Table 4. Relationship between ice nucleation-active bacteria and frost damage occurred on April 29, 1989 under natural conditions ${ }^{a}$

\begin{tabular}{|c|c|c|c|c|c|c|c|c|c|c|}
\hline \multirow{3}{*}{ Site } & \multirow{3}{*}{$\begin{array}{c}\text { Intensity } \\
\text { of } \\
\text { damage }\end{array}$} & \multirow{3}{*}{$\begin{array}{l}\text { Number } \\
\text { of buds } \\
\text { tested }\end{array}$} & \multicolumn{8}{|c|}{ No. of buds carried INA bacteria } \\
\hline & & & \multicolumn{4}{|c|}{ E. ananas } & \multicolumn{4}{|c|}{ X. campestris } \\
\hline & & & $3+$ & $2+$ & + & - & $3+$ & $2+$ & + & - \\
\hline \multirow{3}{*}{ Frosted } & Severe & 54 & 0 & $\begin{array}{c}1 \\
(1.9)\end{array}$ & $\begin{array}{c}1 \\
(1.9)\end{array}$ & $\begin{array}{c}52 \\
(96.3)\end{array}$ & $\begin{array}{c}1 \\
(1.9)\end{array}$ & 0 & $\begin{array}{c}1 \\
(1.9)\end{array}$ & $\begin{array}{c}52 \\
(96.3)\end{array}$ \\
\hline & Light & 54 & 0 & 0 & 0 & $\begin{array}{c}54 \\
(100)\end{array}$ & $\begin{array}{c}1 \\
(1.9)\end{array}$ & 0 & 0 & $\begin{array}{c}53 \\
(98.1)\end{array}$ \\
\hline & None & 54 & 0 & 0 & 0 & $\begin{array}{c}54 \\
(100) \\
\end{array}$ & $\begin{array}{c}2 \\
(3.7) \\
\end{array}$ & 0 & 0 & $\begin{array}{c}52 \\
(96.3) \\
\end{array}$ \\
\hline $\begin{array}{l}\text { Not } \\
\text { frosted }\end{array}$ & None & 54 & 0 & 0 & 0 & $\begin{array}{c}54 \\
(100)\end{array}$ & 0 & 0 & 0 & $\begin{array}{c}54 \\
(100)\end{array}$ \\
\hline
\end{tabular}

a) Explanatory remarks: see Table 1 .

Table 5. Effect of ice nucleation-active bacteria on freeze injury of young new shoots sampled at tea fields and sterilized with sodium hypochlorite after removing a folded terminal leaf Experiment 1

\begin{tabular}{|c|c|c|c|c|c|c|c|c|c|c|c|}
\hline Time in minute & & 0 & 3 & 6 & 9 & 12 & 15 & 18 & 21 & 24 & 27 \\
\hline \multirow{2}{*}{$\begin{array}{l}\text { Temperature, } \\
\left({ }^{\circ} \mathrm{C}\right)\end{array}$} & leaf & 18.3 & 7.3 & 1.1 & -1.3 & -2.2 & -2.1 & -2.7 & -2.1 & -2.9 & -3.2 \\
\hline & air & 19.9 & 7.5 & 0.4 & -2.5 & -4.9 & -4.6 & -5.3 & -5.4 & -5.5 & -5.5 \\
\hline \multicolumn{5}{|c|}{$\begin{aligned} \text { Freeze injury index } & \text { : } \\
& \text { shoots with INA bacteria } \\
& \text { shoots without INA bacteria }\end{aligned}$} & $\begin{array}{l}100 \\
100\end{array}$ & & & & & & \\
\hline \multicolumn{12}{|l|}{ Experiment 2} \\
\hline Time in minute & & 0 & 3 & 6 & 9 & 12 & 15 & 18 & 21 & & \\
\hline $\begin{array}{l}\text { Temperature. } \\
\text { (C) }\end{array}$ & $\begin{array}{l}\text { leaf } \\
\text { air }\end{array}$ & $\begin{array}{l}15.8 \\
15.0\end{array}$ & $\begin{array}{l}6.6 \\
6.5\end{array}$ & $\begin{array}{l}0.2 \\
0.3\end{array}$ & $\begin{array}{l}-1.6 \\
-1.7\end{array}$ & $\begin{array}{l}-1.9 \\
-2.1\end{array}$ & $\begin{array}{l}-2.1 \\
-2.3\end{array}$ & $\begin{array}{l}-2.4 \\
-2.7\end{array}$ & $\begin{array}{l}-2.4 \\
-2.7\end{array}$ & & \\
\hline \multicolumn{5}{|c|}{$\begin{aligned} \text { Freeze injury index: } & \text { shoots with INA bacteria } \\
& \text { shoots without INA bacteria }\end{aligned}$} & $\begin{array}{l}88.9 \\
94.4\end{array}$ & & & & & & \\
\hline
\end{tabular}

a) Severity of freeze injuries was arbitrarily categorized as follows : $3:$ all leaves of a shoot was totally damaged, 2 : about a half of leaves or leaf areas were damaged, $1:$ leaves were slightly damaged, and $0:$ no injury.

Freeze index was calculated by the formula :

Freeze index $=\left(3 n_{1}+2 n_{2}+1 n_{3}+0 n_{1} / 3 N\right) \times 100$

where $n_{1}, \cdots, n_{4}$ are number of shoots for respective category and $N$ is the total number of shoots used.

\section{Relationship between the population of INA bacteria and occurrence of frost injury under natural conditions}

A similar survey of INA bacteria was conducted in a farmer's field where severe frost damage 
Table 6. Effect of ice nucleation-active bacteria on freeze injury of young shoots grown aseptically on the modified MS mediun

Experiment 1

\begin{tabular}{|c|c|c|c|c|c|c|c|c|c|}
\hline Time in minute & & 0 & 3 & 6 & 9 & 12 & 15 & 18 & 21 \\
\hline \multirow[t]{2}{*}{ Temperature, $\left({ }^{\circ} \mathrm{C}\right)$} & leaf & 1.0 & -3.0 & -5.5 & -6.1 & -5.9 & -6.6 & -6.8 & -6.8 \\
\hline & air & 1.3 & -0.1 & -6.1 & -6.8 & -6.6 & -7.2 & -7.5 & -7.3 \\
\hline \multirow{2}{*}{\multicolumn{4}{|c|}{$\begin{array}{r}\text { Freeze injury index }{ }^{\text {a) }} \text { : shoots with INA bacteria } \\
\text { shoots without INA bacteria }\end{array}$}} & 67.0 & & & & & \\
\hline & & & & 50.5 & & & & & \\
\hline \multicolumn{10}{|l|}{ Experiment 2} \\
\hline Time in minute & & 0 & 3 & 6 & 9 & 12 & 15 & 18 & \\
\hline \multirow[t]{2}{*}{ Temperature, $\left({ }^{\circ} \mathrm{C}\right)$} & leaf & 2.0 & -0.9 & -2.5 & -2.9 & -3.0 & -3.2 & -3.0 & \\
\hline & air & 2.2 & -1.4 & -3.4 & -3.7 & -3.4 & -3.5 & -3.2 & \\
\hline \multirow[t]{2}{*}{ Freeze injury index } & : shoo & th IN & acteria & 26.7 & & & & & \\
\hline & shoo & thout & bacteria & 27.8 & & & & & \\
\hline
\end{tabular}

a) See Table 5 .

happened to occur on April 29, 1989 by accidental halting of electricity in early morning. The relationship between INA bacteria and frost damage shown in Table 4 was essentially identical with those in artificial frost, although the population of INA bacteria in this field was significantly lower than that in other fields.

\section{Effect of INA bacteria on freeze injury of aseptic tea shoots}

A strain of INA-X. campestris (IIIB-12) was used as the ice nuclei. The strain was consistently proved to be highly ice nucleation-active during the experiments. The experiments were repeated many times with use of both the surface sterilized new shoots taken from field and plantlets from different batches of tissue culture. The representative results are shown in Tables 5 and 6 . The freeze temperature was -2.0 to $-3.0^{\circ} \mathrm{C}$ with field-grown shoots and -2 to $-7^{\circ} \mathrm{C}$ with cultured shoots. In the latter, succulent and tender leaves freezed at higher temperature than rigid and hard ones. However, no positive relationships were obtained between the presence of INA bacteria and the frequency as well as the intensity of freezing injuries.

\section{DISCUSSION}

The relationship between INA-bacteria and frost damage of tea plant was first discussed by Makino ${ }^{20}$, although his bacterium was identified to be Enwinia ananas afterward ${ }^{7}$. The present study proved that INA-bacteria inhabiting in gemmisphere of tea plants consisted of two bacteria i.e., a new subspecies of Xanthomonas campestris and E. ananas ${ }^{7}$. The former was dominant either in the distribution frequency or in the population. This profile of INA-bacteria on tea plant was distinct from those of other plants in that $P$. fiuorescens, $P$. syringae or $P$. viridiflava were scarcely detected ${ }^{7.9}$. General trends of distribution and population dynamics of INA-bacteria on tea plant were similar to those of INA-bacteria on deciduous fruit trees ${ }^{12)}$.

The distribution and population dynamics of INA bacteria on tea plants growing in bushes at abandoned fields were different from those in ordinary fields under proper managements. This fact implies that nutrition of tea plant greatly affects the microbial flora of tea gemmisphere including INA bacteria. $E$. ananas seemed likely to inhabit preferably on young plants because this bacterium has been detected with relatively high frequency either on potted small plants ${ }^{7}$ or on first new flush developed from stubs which were cut down for regeneration, otherwise being detected only occasionally or at very low populations.

No relationships was observed between INA-bacteria and frost damage either in the analyses conducted under natural conditions or in artificial frost experiments. Frost damage occurred regardless of the frequencies and/or populations of INA-bacteria. The artificially induced frost in this experiments was identical to natural frost in the sense that it was generated through emission of infra-red radiation 
from leaf surface. The frost occurred when temperature just before sunrise declined to $-3^{\circ} \mathrm{C}$. This temperature was equivalent to the highest temperature of INA bacteria, $X$. campestris and $E$. ananas, to break supercooling.

Occurrence of freeze injuries at higher temperatures in the absence of INA-bacteria was repeatedly confirmed with the surface-sterilized tea shoots as well as the aseptically cultured shoots. The tissue of these shoots was confirmed to be free of microorganisms internally or externally by conventional detection method with nutrient agar plates. The young leaves just after unfolding in fields always suffered freeze injuries at -2 to $-3^{\circ} \mathrm{C}$ which was identical to the temperatures at which frost damage occurred under natural conditions. Artificial infestation of these leaves with INA bacteria had no effect on freezing temperature. On the shoots in tissue culture, in contrast, freeze injuries developed at -3 to $-7^{\circ} \mathrm{C}$ depending on the stiffness of the tissue, those with tender leaves being more susceptible to freezing. No difference was also observed in the freezing temperatures of shoots with and without artificial infestation of INA bacteria.

The absence of correlations between INA bacteria and frost damages or freeze injuries described above implies that the intrinsic ice nucleators within plant tissue or the constitutive components of young tea leaves are responsible for initiating ice formation in tea leaves/buds. Therefore, it could be concluded that INA bacteria have only minor importance, if any, on the initiation of frost damage of tea plant. The similar relationships between INA bacteria and frost damage have already reported in the field oriented research e.g., frost damage of deciduous fruit trees such as peach and sweet cherry $^{3,5,11,12\}}$.

\section{Literature cited}

1. Anderson, J.A., Buchanan. D.W. and Stall, R.E. (1984). Reduction of bacterially induced frost damage to tender plants. J. Amer. Soc. Hort. Sci. 109: 401-405.

2. Anderson, J.A., Buchanan, D.W., Stall, R.E. and Hall, C.B. (1982). Frost injury of tender plants increased by Pseudomonas syringae van Hall. J. Amer. Soc. Hort. Sci. $107: 123-125$.

3. Andres, P.K. and Proebsting, E.L., Jr. (1986). Ice nucleation and supercooling in freeze-sensitive peach and sweet cherry tissues. J. Amer. Soc. Hort. Sci. 111 : 232-236.

4. Arny, D.C., Lindow, S.E. and Upper, C.D. (1976). Frost sensitivity of Zea mays increased by application of Pseudomonas syringae. Nature $262: 282-284$.

5. Ashworth, E.N., Anderson, J.A. and Davis, G.A. (1985). Properties of ice nuclei associated with peach trees. J. Amer. Soc. Sci. $110: 287-291$.

6. Azad, H. and Schaad, N.W. (1988). The relationship of Xanthomonas campestris pv. translucens to frost and the effect of frost on black chaff development in wheat. Phytopathology 78:95-100.

7. Goto, M., Huang, B.-L., Makino, T., Goto, T. and Inaba, T. (1988). A taxonomic study on ice nucleationactive bacteria isolated from gemmisphere of tea (Thea sinensis L.), phyllosphere of vegetables, and flowers of Magnolia denudata Desr. Ann. Phytopath. Soc. Japan 54 : 189-197 (in Japanese with English summary).

8. Goto, M., Kodama, K. and Huang, B.-L. (1990). Selective media for ice nucleation-active bacteria of tea buds. Ann. Phytopath. Soc. Japan. $56: 515-522$.

9. Goto, M., Goto, T. and Inaba, T. (1989). Identification of ice nucleation-active bacteria isolated from frost-damaged vegetable leaves. Ann. Phytopath. Soc. Japan 55 : 330-335.

10. Goto, T., Inaba, T. and Goto, M. (1988). Effect of chemical treatments on the frost damage of broccoli sprayed with ice nucleation-active bacterium, Xanthomonas campestris subsp. Proc. Assoc. Pl. Prot. Shikoku, 23 : 57-59 (in Japanese with English summary).

11. Gross, D.C. (1984). The effects of ice nucleation-active bacteria on temperatures of ice nucleation and freeze injury of Prunus flower buds at various stages of development. J. Amer. Hort. Sci. 109 : 375-380.

12. Gross, D.C., Cody, Y.S., Proebsting, E.L., Jr., Radamaker, G.K. and Spotts, R.A. (1983). Distribution, population dynamics, and characteristics of ice nucleation-active bacteria in deciduous fruit tree orchards. Appl. Environ. Microbiol. 46: 1370-1379.

13. Kim, H.K., Orser, C., Lindow, S.E. and Sands, D.C. (1987). Xanthomonas campestris pv. translucens strains active in ice nucleation. Plant Dis. $71: 994-997$.

14. Lindow, S.E. (1983). Methods of preventing frost injury caused by epiphytic ice-nucleation-active bacteria. Plant Dis. 67 : $327-333$.

15. Lindow, S.E., Arny, D.C. and Upper, D.C. (1978). Distribution of ice nucleation-active bacteria on plants in 
nature. Appl. Environ. Microbiol. 36: 831-838.

16. Lindow, S.E., Arny, D.C. and Upper, D.C. (1982). Bacterial ice nucleation : a factor in frost injury to plants. Plant Physiol. 70: 1084-1089.

17. Lindow, S.E. and Connell, J.H. (1984). Reduction of frost injury to almond by control of ice nucleation active bacteria. J. Amer. Hort. Sci. 109: 48-53.

18. Lindow, S.E., Hirano, S.S., Barchet, W.R., Arny, D.C. and Upper, D.C. (1982). Relationship between ice nucleation frequency of bacteria and frost injury. Plant Physiol. 70 : 1090-1093.

19. Maki, L.R., Galyan, E.L., Chang-Chien, M.M. and Caldwell, D.R. (1974). Ice nucleation induced by Pseudomonas syringae. Appl. Microbiol. 28 : 456-459.

20. Makino, T. (1983). Ice-nucleation activity of bacteria isolated from gemmisphere of tea trees. Ann. Phytopath. Soc. Japan 49:32-37 (in Japanese with English summary).

21. Marshall, D. (1988), A relationship between ice-nucleation-active bacteria, freeze damage, and genotype in oats. Phytopathology 78 : 952-957.

22. Vali, G. (1971). Quantitative evaluation of experimental results on the heterogeneous freezing nucleation of supercooled liquids. J. Atmos. Sci. 28: 402-409.

\section{和 文 摘 要}

\section{後藤正夫・駒場雅彦・堀川知廣・中村順行：チャ芽の霜害に及ほす皮核活性細菌の役割}

チャ樹の芽及び新芽の芯柋からは, 1 芽当り平均 $2.8 \times 10^{6}$ 個 $\left(4.8 \times 10^{7} / \mathrm{g}\right)$ の芽圈細菌が検出された。これはオレンジ 色の集落を形成するグラム陽性, 非芽胞形成, 非氷核活性細菌を多数含む点で特徵があった。氷核活性細菌はこれら芽 圈細菌の一部を構成し, 葉が展開すると急速にその密度を低下した。チャ芽における氷核活性細菌密度の季節的変動を 調べた結果，分布頻度・菌数ともに Xanthomonas campestris が主要な氷核活性細菌であることが明らかになった。 Envinia ananas は台刈チャ園の初期萌芽や荒廃チャ園の芽で高い密度を示すなど, 前者とは異なった特徽を示した。 本実験ではこれ以外の氷核活性細菌は検出されなかった。赤外線放射による人口霜害及び自然霜害を受けた新芽から 氷核活性細菌を分離して霜害への役割を検討した。被害程度を異にする芽及び非被害芽の問では, 水核活性細菌の密度 に有為な差は認められず, 霜害が水核活性細菌の存在とは関わりなく発生することを示唆した。また組織培養した無菌 チャ芽と、表面消毒した若い新芽に氷核活性細菌を接種して低温処理し，凍害に及ほすす水核活性細菌の影響を調へた。 その結果凍害の発生温度は氷核活性細菌の存在によって全く影響を受けなかった。以上の実験結果からー3 $\mathrm{C}$ 前後の比 較的高い温度域で発生するチャ芽の霜害では,植物起源の氷核活性物質が重要な意味を持ち,氷核活性細菌の役割は無 視し得る程度のものであろうと考えられた。 